\title{
The influence of public debt on the performance of the economy
}

\author{
Jan Mareček ${ }^{1}$, Veronika Machová ${ }^{*}$ \\ ${ }^{1}$ Institute of Technology and Business in České Budějovice, School of Expertness and Valuation, \\ Okružní 517/10, 37001 České Budějovice
}

\begin{abstract}
Thanks to public debt, nations maintain a stable tax rate and at the same time raise expenses for suppressing budget crises. Public debt is considered risk-free and is issued by the national government. However, extensive public debt raises interest rates, extrudes private investments, worsens fixed balance, widens short-term fluctuation and has a negative impact on economic growth. The performance of the economy can be measured mostly by GDP, which is expressed as the monetary value of all finished products and services produced in a certain time period in one country. The aim of this paper is to explore the relationship, or rather identify the mutual correlation of public debt of one country and its performance (GDP). The research includes countries of the European Union, which have an identifiable timeline of public debt and GDP. The source of this data is the database of the World Bank. The information is from the period of years from 1995 through 2015. The correlation of the whole file of countries and then individual countries is ascertained. On the basis of the results, we can state that in the explored sample of countries, high dependence between public debt and GDP has been proven.
\end{abstract}

Key words: performance of the economy, public debt, HDP, taxes

\section{Introduction}

Public debt enables countries to maintain stable debt rates and at the same time raise expenses for suppresing budget crises [1]. It is therefore a kind of debt that is issued by the national government. It is theoretically considered risk-free because the government may use certain measures to ensure payment, for example raise taxes, lower expenses or print more money, and therefore erase the need for interest to be paid [2].

Public debt can be divided into internal or external debt. Internal debt is debt towards creditors inside the country of subject and external debt refers to debt from loans from outside the country of subject [3]. Public debt may also be classified in regards to the length of its maturity - short-term and long-term public debt. Short-term debt usually matures within one year, while long-term debt is usually matured after 10 years or more [4].

Current studies argue that large public debt raises interest rates, extrudes private investments, worsens fixed balance and widens short-term fluctuation. Empirical studies have discovered that government debt has a significantly negative effect on economic

\footnotetext{
* Corresponding author: machova@mail.vstecb.cz
} 
growth [5]. On the basis of these arguments it is therefore very important to ask if the public debt in a subject country is excessively high and potentionally harmful, and eventually try to change the current state using certain resources [6].

Public debt is usually done on the basis of lending government bonds and issuing securities [7]. Countries which are less creditworthy than others borrow directly from world-wide organizations such as the World Bank and other international financial institutions [8].

This paper analyzes the influence of public debt on the performance of the economy. This performance can be measured mainly by the gross domestic product (GDP). GDP is therefore one of the most important economic indexes which represents the outlook of the national economy. It is therefore very important to determine the forecasts and estimates of GDP according to official statistic data [9].

GDP measures the financial value of all production of all goods and services in a subject country during a certain time period. It creates the economic performance of a country or regions and is important for comparing the differences between the standard of living in subject countries. In general, there are three methods for determining GDP, specifically on the basis of production, expenditure and revenues [10]. Individual methods will be described later. GDP is therefore expressed as the monetary value of all finished products and services produced in a certain time period in one subject country. GDP is usually calculated on a yearly basis, it is however possible to calculate it quarter-yearly [11]. GDP encompasses all private and public consumption, investments, government spending, private resources, paid construction expenses and foreign commercial balance. GDP thus determines the economic performance of the country [12].

GDP is therefore a measure of consumer expenditure (C) plus business investment (I) and government spending $(\mathrm{G})$, as well as net exports, which are exports without imports (X-M). The dynamics of the GDP structure by revenue category reflects a real reduction in household incomes and a growing tax burden [13]. GDP can be measured by the expenditure or production method. The expenditure method is based on the ascertainment and sum of the amounts for purchases of final products and services in a single year, including consumer spending, capital expenditures, government expenditures and net exports. The production method, also referred to as a pure product method, is based on the value of the produced goods or services, usually per year. Firstly, the gross value of production is estimated in all sectors. Intermediate consumption, such as the cost of materials, supplies and services used in final output, is then deducted, and then gross output is reduced by intermediate consumption to develop net output $[14,15]$. GDP is measured not only by the expenditure and production method, but also by the pension method. This method of determining GDP is complemented by all incomes of households and firms. Total expenses for all final goods and services are income earned as wages, profits, rents and interest. By combining all wages, profits, rents and interest, it is possible to determine GDP $[16,17]$.

The aim of the paper is to examine the relationship, or rather to identify the correlation between the amount of the country's debt and its performance.

\section{Data and methods}

The survey will include countries in the European Union where we will be able to identify the timeline of public debt and gross domestic product (GDP). Data will be obtained from the World Bank database (The World Bank, 2017). The data will be from a period of twenty one years, namely 1995-2015. These countries will be Belgium, Bulgaria, the Czech Republic, Denmark, Estonia, Finland, France, Ireland, Italy, Lithuania, Latvia, 
Luxembourg, Cyprus, Hungary, Malta, Greece, Slovakia, Slovenia, Spain, Sweden and the United Kingdom.

All financial data is in millions of Euro. We will be basing it on the following formula:

$$
\rho_{x, y=\frac{\operatorname{Cov}(X, Y)}{\sigma_{x *} \sigma_{y}}}
$$

where $\overline{\mathbf{x}} \mathbf{a} \overline{\mathbf{y}}$ are the mean values of GDP and public debt.

We will examine the correlation of both the entire selection, i.e. for the whole set of countries, and for each country of the data set.

\section{Results}

As already indicated in the methodology, the correlation of the entire set of states will first be examined, then the correlation for each country of the data file.

\subsection{Measurement of the whole set of countries}

When we apply all data from the dataset, that is to say, for all observed countries, we get a correlation coefficient of 0.882 . This is a very high dependence of both quantities. The result predicts interesting results on the national level. If we want to interpret the value of 0.882 , we must unequivocally state that the level of GDP is very much influenced by the size of the public debt of the surveyed sample of countries. We can even conclude that the higher the value of the public debt, the higher the total GDP of the surveyed group of countries. It will certainly be very interesting how the country's correlation will develop. We will surely have to focus our attention on, let's say, the countries troubled in the past. Specifically in regards to problems with debt (ideally in relation to GDP). In particular, we should continue to focus on Greece, which is still very much confronted with the effects of the global economic crisis. A very interesting country from this point of view will also be Italy, whose debt is also extremely high in relation to GDP.

\subsection{Measurement of individual countries of the examined file}

Table 1 provides the country-by-country correlation coefficients and the GDP of each country of the surveyed file. 
Table 1. Correlation coefficients of public debt and GDP of countries surveyed.

\begin{tabular}{|l|r|l|r|}
\hline \multicolumn{1}{|c|}{ Country } & Correlation coefficient & \multicolumn{1}{c|}{ Country } & Correlation coefficient \\
\hline Poland & 0,978795773 & Portugal & 0,847339537 \\
\hline Germany & 0,953788009 & Cyprus & 0,812400833 \\
\hline Czech Republic & 0,949450649 & Slovenia & 0,79948063 \\
\hline Hungary & 0,94506547 & United Kingdom & 0,780284517 \\
\hline Belgium & 0,920808469 & Finland & 0,759296546 \\
\hline Slovak Republic & 0,914040138 & Bulgaria & 0,727560281 \\
\hline Austria & 0,905395381 & Ireland & 0,726590126 \\
\hline Romania & 0,887252931 & Malta & 0,675399045 \\
\hline Italy & 0,8844445598 & Spain & 0,616071299 \\
\hline France & 0,878382158 & Greece & 0,587727189 \\
\hline Latvia & 0,877541173 & Denmark & 0,538750292 \\
\hline Luxembourg & 0,857657409 & Sweden & 0,53259842 \\
\hline Lithuania & 0,857575759 & Netherlands & 0,398606968 \\
\hline Estonia & 0,847928938 & & \\
\hline
\end{tabular}

The results are sorted by the correlation coefficient. For a better view, the data was inserted into the chart in Figure 1.

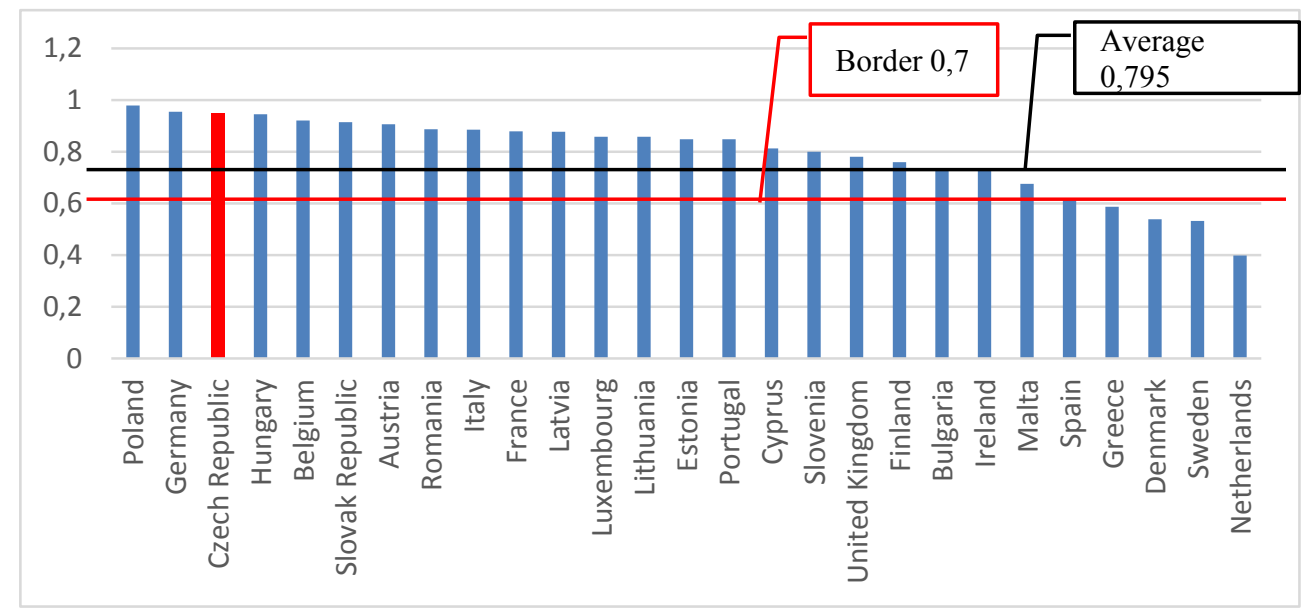

Fig. 1. Coefficients of country correlation.

The figure shows that Poland's value was the highest, almost 0.98 . On the contrary, the lowest correlation value can be observed for the Netherlands, almost 0.4 . We can consider the value 0.7 to be the border of large interdependence of the monitored quantities. The average correlation coefficient of the monitored set of countries is 0.795 . This is a very high value. This average basically means that the correlation coefficient of all data surveyed has linked national debt and GDP not only within the country but also across the surveyed sample. However, this does not change the fact that even the average correlation coefficient is very high. Of the 27 countries surveyed, 17 countries are above the average correlation coefficient. For 22 countries, we can talk about a high degree of dependence. Only 5 countries have a lower degree of dependency. In addition, only one country, namely the Netherlands, is below the correlation coefficient of 0,5 .

The Czech Republic is highlighted in red. In this case, the correlation coefficient is 0.949. In the list of countries surveyed, it occupies the third place. The interdependence of state debt and GDP is exceptionally high in the Czech Republic. 
We will now focus on selected countries and analyze the evolution of public debt and GDP over the period under review.

First, let's look at Poland, which shows the highest degree of public debt and GDP in all the countries surveyed. Development is the subject of figure 2.

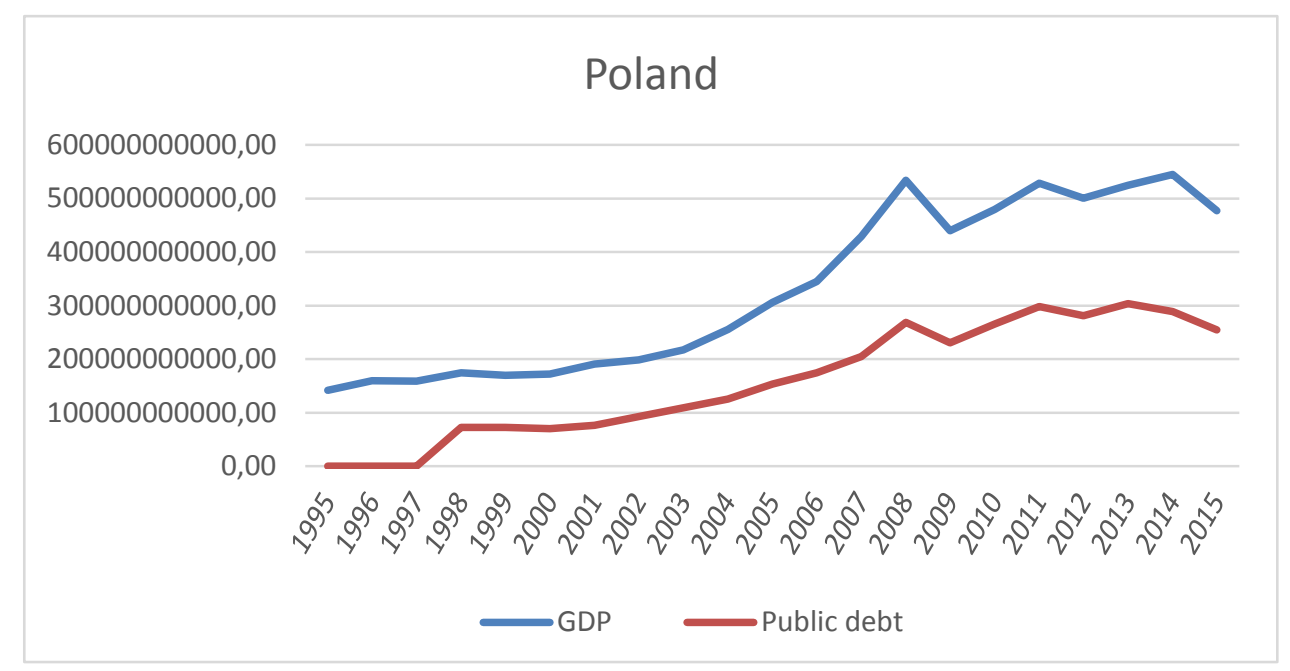

Fig. 2. Poland - Public Debt Development and GDP.

It is clear from the picture that public debt and GDP have developed over the whole period under review in exactly the same way. Any fluctuations in public debt developments are immediately reflected in the GDP. We can say that the higher the state debt, the higher the GDP. It can be seen that Poland is using its available resources very efficiently. In addition, its economy has high potential. If Poland does not reach its production caps, further increases in public debt may be recommended.

The second country to be studied is the Czech Republic. The situation is depicted in the figure in Figure 3.

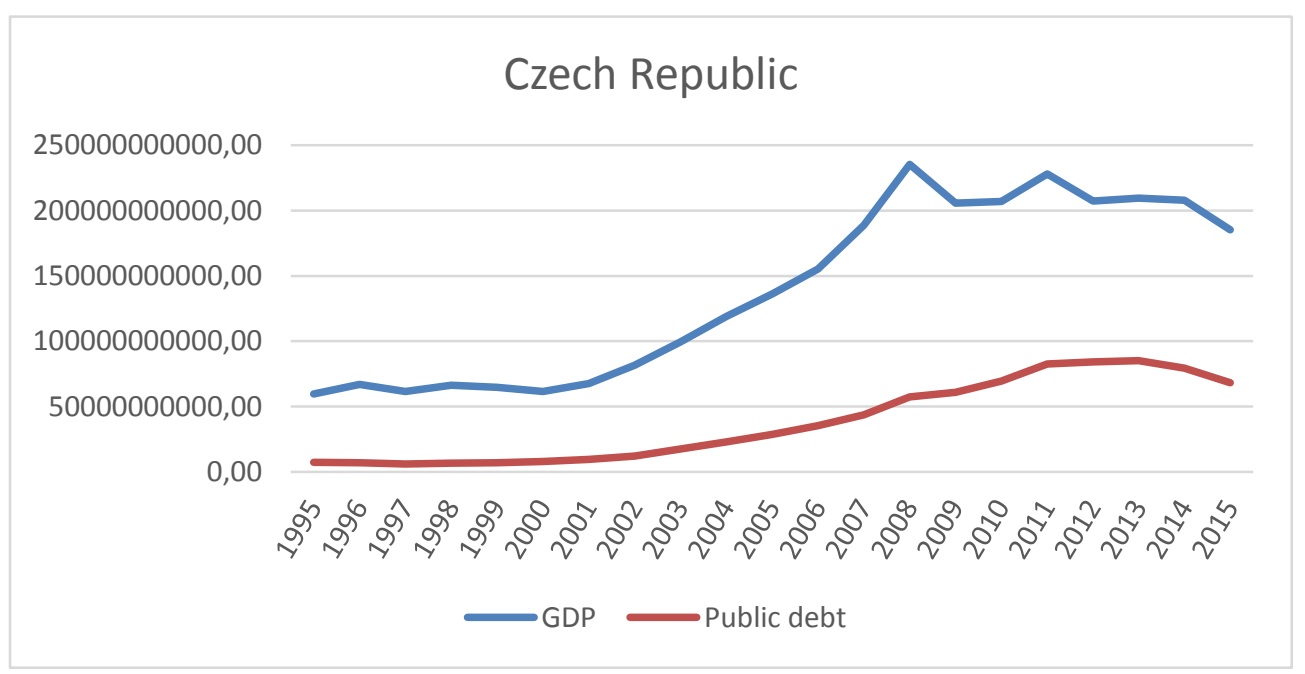

Fig. 3. Czech Republic - Public Debt and GDP Developments. 
The Czech Republic also has a very high dependence on public debt and GDP. However, it is clear from the picture that the two variables do not develop as plastically as in the case of Poland. We can state that the Czech Republic also uses its resources in an efficient way. We can also say that the Czech Republic has a great potential. However, there is a certain delay between the use of foreign funds (ie public debt) and the result in the form of GDP. In addition, fluctuations are eroding, particularly in 2008. This could of course be caused by the economic crisis. However, in the case of Poland, the delay did not occur. Figure 4 shows the situation in Italy.

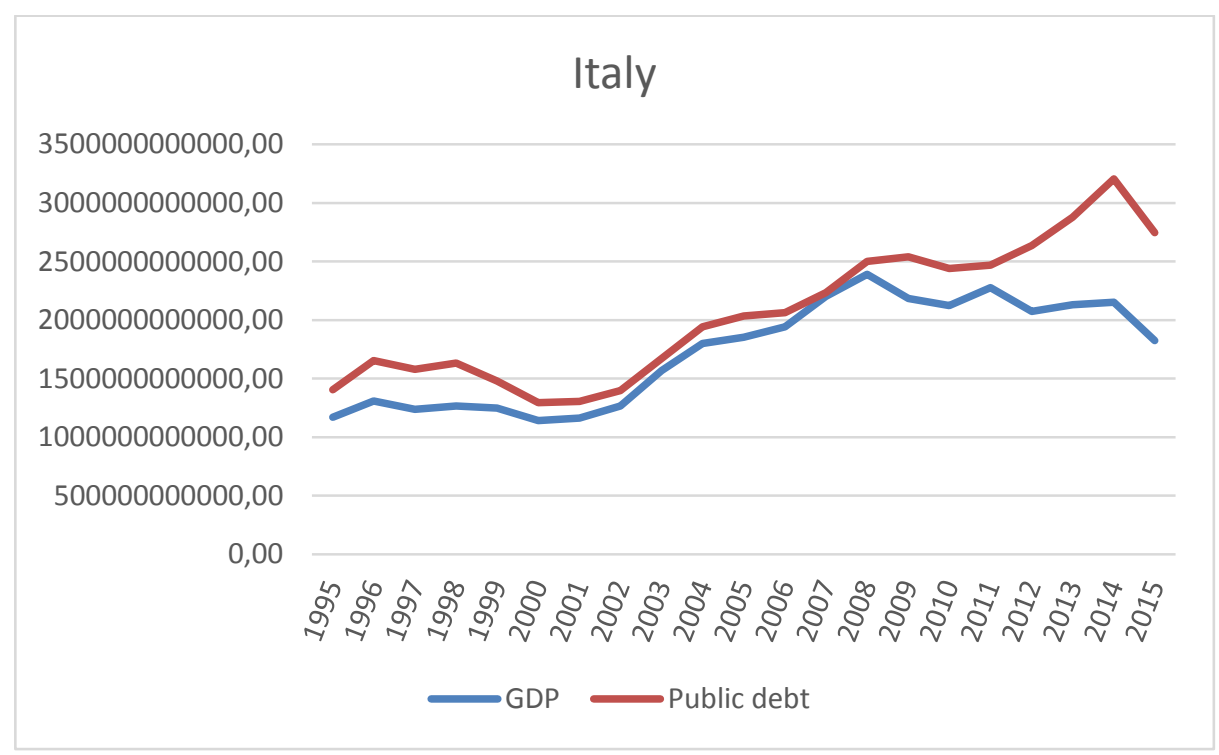

Fig. 4. Italy - Developments in public debt and GDP.

Unlike Poland and the Czech Republic, Italy has had a relatively high debt ratio throughout the period under review. The Czech Republic and Poland had their public debts at around $60 \%$ or less of GDP. By contrast, Italy's public debt is above GDP. It is clear that the interest that Italy has to pay for its debts is enormous and GDP growth slows down. In 2015 , Italy's public debt is about $130 \%$ of GDP. However, despite this high debt ratio, Italy has a rate of public debt and GDP of 0.884 . It can be said that with lower public debt, Italy's economy performance would be significantly lower. We can conclude that Italian national economists are at risk. At present, when Italy is able to pay interest on the use of foreign funds, where the economy is very efficient and overall has great potential, this strategy appears to be very effective, albeit rather risky. If we look from the other side to the dependence of the two variables, it is clear that the correlation is not 1 . This means that the dependence is not absolute and the remaining 0.116 (some independence, some inefficiency in the use of foreign sources) should be used by Italy to reduce its public debt, at least at the time of its growth.

From the point of view of the interpretation of the state debt and GDP development, Greece is a very interesting country that has faced problems since the world economic crisis. Government debt and GDP growth in Greece is the subject of figure 5. 


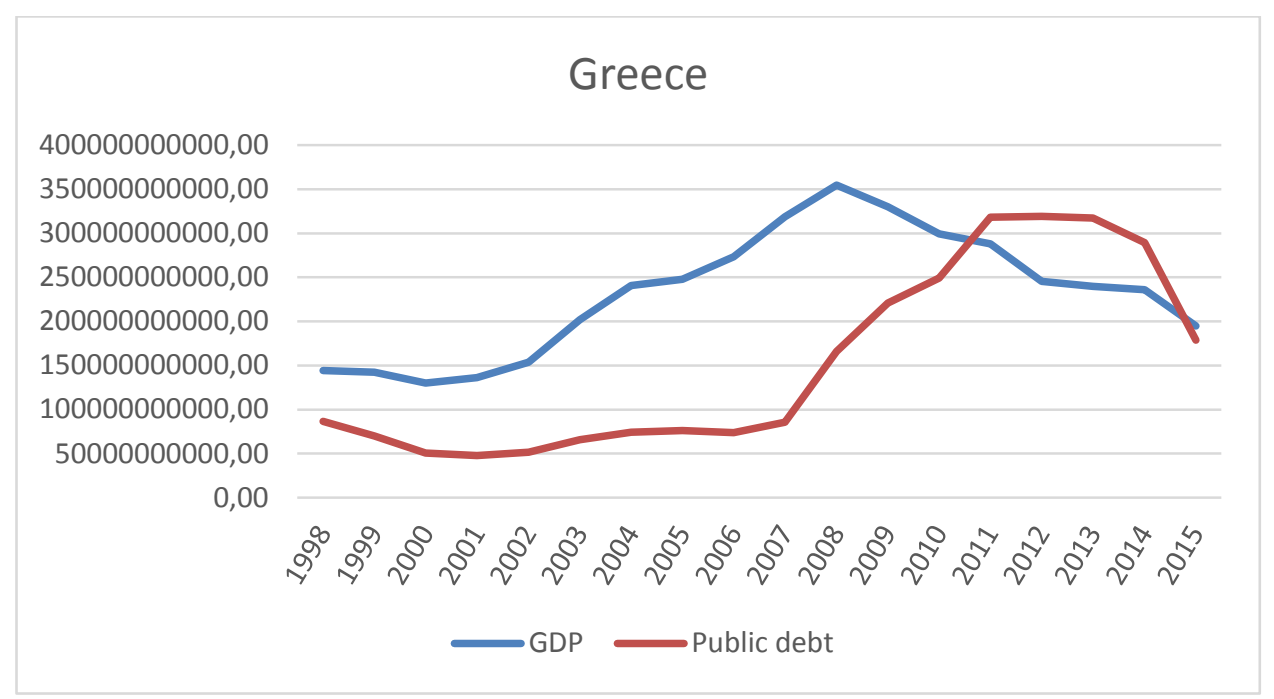

Fig. 5. Greece - public debt and GDP growth.

The correlation coefficient of public debt and Greece's GDP is around 0.588. This is the dependence of the two variables, though not extreme. Dependence can be seen in the picture by 2007. However, in the first year of the global economic crisis, the situation is changing. GDP is beginning to fall rapidly. Conversely, public debt is rising sharply. In 2011, the public debt exceeds the level of GDP. Subsequently, public debt stagnates and begins to decline. In 2015 it is again below GDP. This is the result of the Greek government's saving measures (including the overall restructuring of the Greek public debt) and the pressure of the international community. However, it is clear that Greece's public debt is a burden for its country and, unlike other countries, slows down the performance of the economy. This is due to the amount of interest paid and probably the reluctance of other countries to lend money to Greece. Sweden is also interesting for the result, as shown in Figure 6.

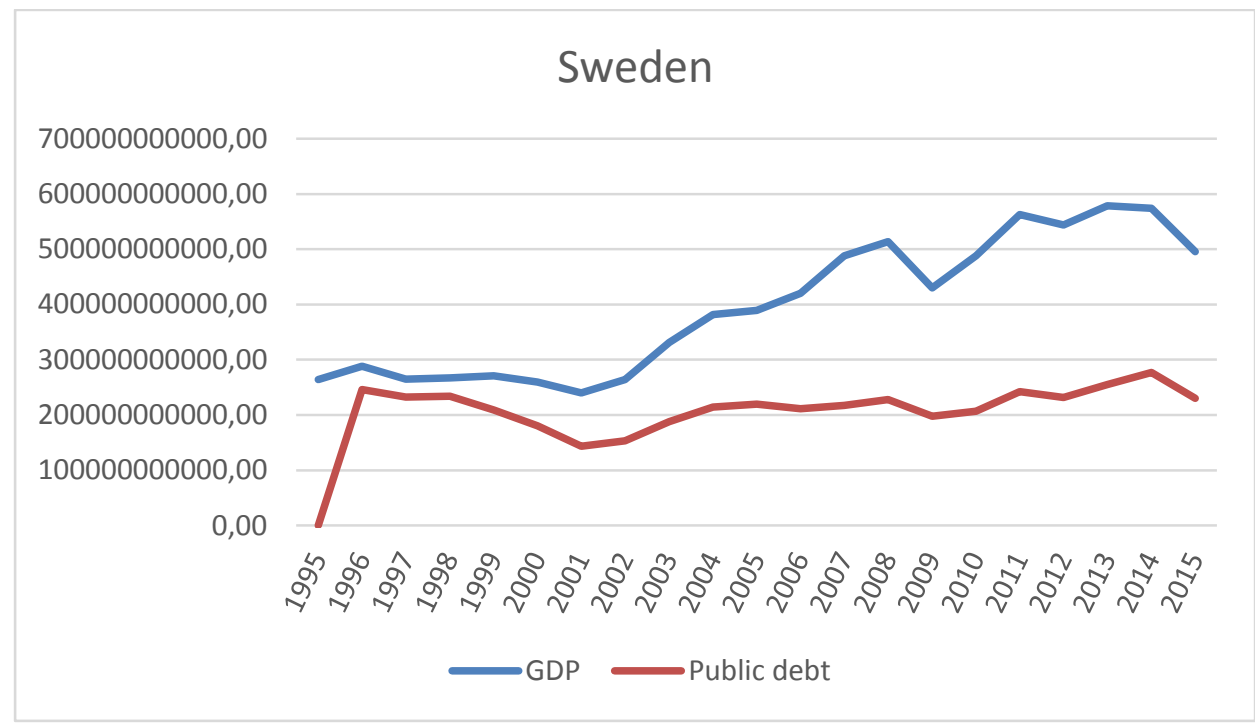

Fig. 6. Sweden - Public debt and GDP growth. 
Sweden has a correlation coefficient of 0.532 . This is the second lowest value in the surveyed countries. The public debt of Sweden is relatively low in relation to GDP. It is clear that Sweden does not need foreign funds to grow, and does not use these funds.

\section{Conclusion}

The aim of the paper was to explore the relationship, or rather to identify the correlation between the amount of the country's debt and its performance.

On the basis of the results, we can state that a large dependence of public debt and GDP has been demonstrated in the sample of countries surveyed. In the case of the 22 countries surveyed, headed by Poland and Germany, a rise in public debt may be recommended. The result will most likely increase their GDP.

In 5 countries, it is not advisable to recommend a rise in public debt. Either a country with a high state debt (Greece) or a country where debt growth will not mean a rise in the economy's performance (Sweden, the Netherlands).

The goal of the paper was met.

\section{References}

1. M. A. Allen, M. Digiuseppe, Tightening the Belt: Sovereign Debt and Alliance Formation. International Studies Quarterly, 57(4), 647-659, (2013)

2. F. Fastenrath, M. Schwan, Ch. Trampusch, Where states and markets meet: the financialisation of sovereign debt management. New Political Economy, 22(3), 273 293 (2016)

3. C. Bowdler, R. P. Esteves, Sovereign debt: the assessment. Oxford Review of Economic Policy, 29(3), 463-477 (2013)

4. L. Agnello, V. Castro, J. T. Jalles, R. M. Sousa, Financial stress and sovereign debt composition. Applied Economics Letters, 23(9), 678-683 (2015)

5. M. Caner, T. Grennes, F. Koehler-Geib, Finding the tipping point: When sovereign debt turns bad. Sovereign Debt and the Financial Crisis: Will this Time be Different, 63-75 (2011)

6. J. Xu, X. Zhang, China's sovereign debt: A balance-sheet perspective. China Economic Review, 31, 55-73 (2014)

7. P. Rousek, M. Vochozka, Public production of private and public goods in the Czech Republic in 2013. Proceedings of the 7th International conference Economic Challenges in Enlarged Europe, 1-9, (2015)

8. M. Ehrmann, M. Fratzscher, Euro area government bonds - Fragmentation and contagion during the sovereign debt crisis. Journal of International Money and Finance, 70, 26-44 (2017)

9. V. Bartoseviciene, S. Janusauskaite, S. Motuziene, Prognostication of the gross domestic product. Proceedings of the 2nd International Scientific Conference on Globalisation and Integration Challenges to Rural Development in Eastern and Central Europe, Kaunas City, Lithuania, 211-213, (2005)

10. J. Vrbka, Predicting Future GDP Development by Means of Artificial Intelligence. Littera Scripta, 9(3), 154-167 (2016) 
11. B. He, Consideration of risk in the measurement of gross domestic product and its influence on behavioral change. 2009 ISECS International Colloquium on Computing, Communication, Control, and Management, IEEE, 268-271 (2009)

12. X. Xu, China's gross domestic product estimation. China Economic Review, 15(3), 302-322 (2004)

13. I. Steblianko, Gross domestic product in the categories of production, income and end use. Economic Annals-XXI, 160(7-8), 35-38 (2016)

14. K. Vltavska, J. Sixta, M. Simkova, J. Zeman, Historical time series of GDP employing standard esa 2010. Proceedings of the 9th International Days of Statistics and Economics, Prague, Czech Republic, 1675-1682 (2015)

15. T. Proietti, M. Marczak, G. Mazzi, Euromind- D: A Density Estimate of Monthly Gross Domestic Product for the Euro Area. Journal of Applied Econometrics, 32(3), 683-703 (2017)

16. D. M. Rees, D. Lancaster, R. Finlay, A State-Space Approach to Australian Gross Domestic Product Measurement. Australian Economic Review, 48(2), 133-149 (2015)

17. B. Yang, C. Li, M. Li, K. Pan A. D. Wang, Application of ARIMA model in the prediction of the gross domestic product. Proceedings of the 6th International Conference on Mechatronics, Computer and Education Informationization, Shenyang, China, 130, 1258-1262 (2016)

18. The World Bank, The World Bank - USA [online], Available from: http://www.worldbank.org/ (2017) 
